Research Article

\title{
Seed Quality as Related to Harvest Time in Three Key Perennial Grasses Native to Puna Tussock Rangelands of Peru
}

\author{
Jimy Castro $\mathbb{D}^{1}{ }^{1}$ Lucrecia Aguirre, $^{1}$ and Roberto Distel ${ }^{2}$ \\ ${ }^{1}$ Laboratorio de Ecología y Utilización de Pastizales, Departamento de Producción Animal, Facultad de Zootecnia, \\ Universidad Nacional Agraria La Molina, La Molina, Lima, Peru \\ ${ }^{2}$ Centro de Recursos Naturales Renovables de la Zona Semiárida (CERZOS), Departamento de Agronomía, \\ Universidad Nacional del Sur (UNS) - CONICET, Bahía Blanca 8000, Argentina \\ Correspondence should be addressed to Jimy Castro; jimycastro@lamolina.edu.pe
}

Received 18 June 2021; Accepted 11 August 2021; Published 29 August 2021

Academic Editor: Isabel Marques

Copyright $\odot 2021$ Jimy Castro et al. This is an open access article distributed under the Creative Commons Attribution License, which permits unrestricted use, distribution, and reproduction in any medium, provided the original work is properly cited.

\begin{abstract}
Seed-based rehabilitation programs represent a primary foundation for rangeland recovery, which requires high-quality seed of key native species. The objective of this research was to determine the seed quality at different harvest times for three key perennial grasses native to puna tussock rangelands of Peru: Festuca dolichophylla, Festuca humilior, and Calamagrostis vicunarum. Seeds of each species were harvested at 21,28, and 35 days after anthesis and evaluated by standard tests to determine the purity, size, viability, and germinability. On average, the seed purity of the studied species ranged between $23 \%$ and $44 \%$, hundred-seed weight between $34 \mathrm{mg}$ and $73 \mathrm{mg}$, seed viability between $24 \%$ and $60 \%$, and the seed germination between $18 \%$ and $34 \%$ over the harvest dates. The highest seed quality was observed in C. vicunarum. Seed quality parameters of the studied species did not show a consistent variation over the harvest times. Overall, the species studied presented relatively low seed quality; therefore, when using it in rehabilitation programs for rangeland recovery, it is important to carry out a previous cleaning process (to reduce nonviable seeds and inert matter) and to use a sufficient quantity of seed for effective establishment of these key grasses.
\end{abstract}

\section{Introduction}

Rangelands under improper grazing management and overutilization deteriorate to varying degrees around the world [1], negatively affecting the provision of ecosystem services and livelihoods for local communities. Hence, there is an urgent need to rehabilitate degraded rangelands, and the seeds of key native species represent a foundation for rehabilitation and restoration programs [2]. However, knowledge of the quality of native seeds (purity, viability, and germinability) is decisive for achieving success [3].

The time of harvesting is a primary determinant of the seed quality of native grasses [4]. Seed physiological maturity (defined as the maximum seed dry matter accumulation) and seed water content represent key considerations for identifying the optimum time for seed harvesting [5]. Harvesting seeds before physiological maturity may result in lightweight seeds of reduced viability, whereas harvesting seeds long after physiological maturity may result in seed lost by shattering. Once seeds reach a maximum dry weight, they undergo an accelerated dehydration phase until a hygroscopic equilibrium is attained and harvest maturity reached [6].

For cool-season grasses, the time from anthesis to harvest maturity varies between species and environmental conditions [5], for instance, it ranged from 25 to 40 days for several cool-season grasses [7-13]. Hot and dry weather conditions accelerate ripening, whereas cool and moist conditions delay ripening. However, besides a reference time from anthesis to harvest maturity, the indeterminate nature of the inflorescence in cool-season grasses poses a problem for identifying an overall optimum harvest time because the seeds in each seedhead are at differing stages of development and maturation at any point in time.

The puna ecoregion is in the central Andean Mountains, from Peru, extending southwards across Bolivia, Chile, and 
Argentina. In Peru, the puna rangelands cover an area of approximately 21 million hectares, at an elevation ranging from $3500 \mathrm{~m}$ to $4800 \mathrm{~m}$ [14]. In these rangelands, livestock such as alpaca, sheep, and/or cattle represent the main source of livelihood for pastoralist communities [15]. However, due to overutilization of the vegetation, the Peruvian puna rangelands have been undergoing degradation for many years, jeopardizing ecological-economic and social sustainability $[16,17]$. Rangeland degradation has caused the loss of key perennial grasses, soil erosion, and reduction in primary and secondary productivity. Therefore, there is an urgent need to help pastoralist communities halt and reverse the process of rangeland degradation. The addition of seeds of key native species represents a primary option for rangeland recovery. So far, however, there is a scarcity of information on the seed quality of key perennial grasses of the puna rangelands. Therefore, the objective of this research was to determine the seed quality at different harvest times for three key perennial grasses native to the puna tussock rangelands of Peru: Festuca dolichophylla J. Presl, Festuca humilior Nees and Meyen, and Calamagrostis vicunarum (Wedd.) Pilg. Seed quality was evaluated by determining the seed purity, size (weight and length), viability, and germinability.

\section{Materials and Methods}

The study was conducted at the Unidad de Producción CONSAC, belonging to the SAIS (Sociedad Agricola de Interés Social) Tupac Amaru Ltda. $\mathrm{N}^{\circ} 1$. The site is in Jauja province $\left(11^{\circ} 55^{\prime} 60^{\prime \prime} \mathrm{S}, 75^{\circ} 41^{\prime} 00^{\prime} \mathrm{W}\right)$, Junin region, Peru, at an elevation of $4164 \mathrm{~m}$. The climate of the region is tropical highland, humid subalpine paramo, with a moderate thermal amplitude [18]. The mean monthly air temperature ranges between $11^{\circ} \mathrm{C}$ in July and $13^{\circ} \mathrm{C}$ in January, with an annual mean of $12^{\circ} \mathrm{C}$. The average frost-free period is 210 days long (October-April). Long-term mean annual rainfall is $700 \mathrm{~mm}$. The wet season (December-April) accounts for around $80 \%$ of the total annual precipitation. During the flowering period of the study year (2016), both the monthly average air temperature and monthly rainfall were similar to the long-term average values. Dominant soils are classified as Mollisols, of sandy loam texture, high in organic matter (7\%), acidic ( $\mathrm{pH} 5)$, moderate in potassium (140 ppm), and low in available phosphorous (6 ppm) [19]. The physiognomy of the vegetation is tussock grassland dominated by the tussock-forming grasses F. dolichophylla, F. humilior, and C. vicunarum, with the forb Alchemilla pinnata growing in the intertussock spaces [19]. These three dominant perennial tussock-forming grasses flower in March (at the end of summer in the southern hemisphere) and disperse their seeds in April. The seeds overwinter in the soil seed bank before they germinate in spring (November-December).

In January 2016, 30 plants of each of the studied species (F. dolichophylla, F. humilior, and C. vicunarum; hereafter, Fedo, Fehu, and Cavi, respectively) were selected and marked correctly. For each species, the plants were of similar size and growth stage. In each selected plant, three inflorescences (seedheads) were marked and checked frequently to establish the time of anthesis (extrusion of the anthers). Since flowering progresses differentially along the inflorescence, the criterion followed to determine anthesis was the protrusion of anthers in approximately half of the florets of the inflorescence. Once the date of anthesis was established at the inflorescence level, the three inflorescences marked per selected plant were randomly assigned to be harvested 21 (beginning of April), 28 (mid of April), or 35 (end of April) days later. The harvest time was not extended beyond 35 days after anthesis because seed shattering began to occur. Inflorescences were cut $5 \mathrm{~cm}$ below the base of the rachis, air-dried at ambient temperature for a month, and finally dry stored at $10^{\circ} \mathrm{C}$. The evaluation of seed quality attributes was carried out seven months after seed harvesting. For seed purity determination, the sample used was the total of the inflorescences, whereas for the rest of the seed quality attributes (seed weight, length, viability, and germinability), the samples used were pure seed lots.

To determine seed purity, all florets in each inflorescence were examined visually with the aid of hand lenses and binocular stereoscopes and sorted into one of three components: pure seed, other seed, and inert matter. The criteria followed to classify a seed as pure was a caryopsis larger than one-third of the palea, measured from the base of the rachilla [20]. Seed purity was calculated as the ratio of pure seed weight to the total weight of the sample used and expressed as a percentage. Due to the limited amount of pure seed and the high variability among individual seeds, the seed weight was determined in one batch of 100 seeds per species for each harvest date. Seed length from the base to the top of the lemma was measured with a Vernier caliper on 50 pure seeds per species per harvest date.

Seed viability was evaluated with the tetrazolium test in four replicates of 10 pure seeds per species per harvest date. Seeds were placed in pill box trays and imbibed in 30 drops of $0.1 \%$ solution of 2,3,5-triphenyltetrazolium chloride, previously cut laterally to expose the embryo and facilitate contact with the tetrazolium solution. They were then incubated at $30^{\circ} \mathrm{C}$ for $16 \mathrm{~h}$. Finally, the seeds were washed with distilled water and observed with a binocular stereo microscope. Seeds were considered living when the embryo developed a red or purple colour. Seed viability was calculated as the ratio of the number of living seeds to the total number of pure seeds and expressed as a percentage.

Germination tests were performed on four replicates of 20 pure seeds per species per harvest date. Seeds were placed in plastic containers (with holes in the lids to allow air movement) between paper towels that were continually moistened with distilled water and were first subjected to a chilling treatment $\left(5^{\circ} \mathrm{C}\right)$ until the emergence of the radicle in the least dormant seeds. This cold-stratification, dormancyrelease treatment stimulates germination of seeds that in nature present winter dormancy [21, 22], as is the case for the species studied. Then, the seeds were transferred to a growth chamber for 35 days, at $75 \%$ relative air humidity, and diurnal cycles of $25^{\circ} \mathrm{C}$ in the light $(8 \mathrm{~h})$ and $15^{\circ} \mathrm{C}$ in the dark $(16 \mathrm{~h})$. These temperature and light conditions resemble the natural conditions to which seeds are exposed when they germinate in spring and were also in the range of 
temperature and light conditions recommended for germination of Festuca species [20]. The seedlings were evaluated every seven days and classified as normal or abnormal based on the development of functional structures (radicle, mesocotyl, and coleoptile), according to [20]. Germination was calculated as the ratio of the number of normal seedlings to the total number of pure seeds and expressed as a percentage.

The statistical design for the ANOVA was a completely randomized factorial design, comprising three species (Fedo, Fehu, and Cavi) and three harvest dates (21, 28, and 35 days after anthesis; hereafter, $\mathrm{H} 1, \mathrm{H} 2$, and $\mathrm{H} 3$, respectively), except for seed weight that was subjected to descriptive statistics because of the lack of replication. Seed purity percentages were square root transformed to meet ANOVA requirements of normality and homoscedasticity, whereas seed length data were analyzed by the nonparametric test of Kruskal-Wallis since no transformation of the data met ANOVA requirements. The significance of the difference between means was tested using the LSD test $(p<0.05)$. All data were analyzed with mixed models in SAS version 9.4 (SAS Inst. Inc., Cary, NC, USA).

\section{Results and Discussion}

Seed purity was affected by harvest date $(p<0.01)$ and by species $(p<0.01)$ (Table 1$)$. There was no interaction $(p>0.05)$ between harvest date and species. Seed purity was similar between H1 (21 days after anthesis) and H3 (35 days after anthesis) and higher than at H2 (28 days after anthesis), whereas it was highest in Cavi, intermediate in Fehu, and lowest in Fedo. The drop in seed purity at $\mathrm{H} 2$ may have been due to environmental conditions, particularly temperatures that were too low or too high (common in the harsh environmental conditions of the puna) that affect anthesis and seed development negatively in cool-season grasses, therefore increasing the inert matter [5]. A similar effect may have been caused by high rainfall intensity during anthesis, which has been shown to reduce seed set in grasses [23]. Moreover, because the florets differed in the date of origin, they were not only potentially exposed to different environmental conditions from anthesis to seed maturity but they also contributed in different relative proportions according to the harvest time. Apart from the impact of the harvest date on seed purity, the differences between species may be due, at least in part, to seed loss by dispersal. Seed dispersal progresses faster in Fedo than in Cavi and Fehu (which was self-evident in the field observations), which may help to explain the lowest seed purity of Fedo. However, the overall seed purity of the studied species was relatively low compared to that of other native grasses, even considering maximum values [24-27]. The harsh environmental conditions (extreme temperatures and high rainfall intensity) in the puna rangelands during seed development may help to explain their relatively low seed purity.

Seed length was affected by harvest date $(p<0.01)$ and by species $(p<0.01)$ (Table 2$)$. It was higher at $\mathrm{H} 3$ than at $\mathrm{H} 1$ and $\mathrm{H} 2$ and highest in Fedo, intermediate in Fehu, and lowest in Cavi. However, there was an interaction $(p<0.05)$
TABLE 1: Seed purity (average \pm 1 SE) of the three perennial grasses studied.

\begin{tabular}{lcccc}
\hline \multirow{2}{*}{ Species } & \multicolumn{4}{c}{ Harvest date } \\
& H1 & H2 & H3 & Average \\
\hline \multirow{4}{c}{$\%$} \\
Fedo & $25 \pm 2.1^{\mathrm{Ba}}$ & $18 \pm 1.7^{\mathrm{cb}}$ & $26 \pm 3.7^{\mathrm{Ca}}$ & $23 \pm 1.5^{\mathrm{C}}$ \\
Fehu & $45 \pm 3.0^{\mathrm{Aa}}$ & $29 \pm 3.2^{\mathrm{Bb}}$ & $38 \pm 3.9^{\mathrm{Bab}}$ & $37 \pm 2.0^{\mathrm{B}}$ \\
Cavi & $41 \pm 3.9^{\mathrm{Aab}}$ & $38 \pm 3.6^{\mathrm{Ab}}$ & $53 \pm 4.9^{\mathrm{Aa}}$ & $44 \pm 2.5^{\mathrm{A}}$ \\
\hline Average & $37 \pm 2.0^{\mathrm{a}}$ & $28 \pm 1.9^{\mathrm{b}}$ & $39 \pm 2.7^{\mathrm{a}}$ \\
\hline
\end{tabular}

Fedo, Festuca dolichophylla; Fehu, Festuca humilior; Cavi, Calamagrostis vicunarum harvested at three times after anthesis (H1, 21 days; $\mathrm{H} 2,28$ days; $\mathrm{H} 3,35$ days). Means with different superscripts in the same row (lowercase letters) or in the same column (uppercase letters) are significantly different $(p<0.05)$.

TABLE 2: Seed length (average $\pm 1 \mathrm{SE}$ ) of the three perennial grasses studied.

\begin{tabular}{lcccc}
\hline \multirow{2}{*}{ Species } & \multicolumn{4}{c}{ Harvest date } \\
& $\mathrm{H} 1$ & $\mathrm{H} 2$ & $\mathrm{H} 3$ & Average \\
\hline \multicolumn{4}{c}{$\mathrm{mm}$} \\
Fedo & $6.7 \pm 0.2^{\mathrm{Ab}}$ & $6.4 \pm 0.1^{\mathrm{Ab}}$ & $7.7 \pm 0.2^{\mathrm{Aa}}$ & $6.9 \pm 0.1^{\mathrm{A}}$ \\
Fehu & $6.2 \pm 0.1^{\mathrm{Ba}}$ & $6.3 \pm 0.1^{\mathrm{Aa}}$ & $6.0 \pm 0.1^{\mathrm{Ba}}$ & $6.2 \pm 0.1^{\mathrm{B}}$ \\
Cavi & $5.0 \pm 0.1^{\mathrm{Ca}}$ & $5.0 \pm 0.1^{\mathrm{Ba}}$ & $5.1 \pm 0.1^{\mathrm{Ca}}$ & $5.0 \pm 0.0^{\mathrm{C}}$ \\
\hline Average & $6.0 \pm 0.1^{\mathrm{b}}$ & $5.9 \pm 0.1^{\mathrm{b}}$ & $6.3 \pm 0.1^{\mathrm{a}}$ \\
\hline
\end{tabular}

Fedo, Festuca dolichophylla; Fehu, Festuca humilior; Cavi, Calamagrostis vicunarum harvested at three times after anthesis ( $\mathrm{H} 1,21$ days; $\mathrm{H} 2,28$ days; $\mathrm{H} 3,35$ days). Means with different superscripts in the same row (lowercase letters) or in the same column (uppercase letters) are significantly different $(p<0.05)$.

between harvest date and species; seed length of Fedo was higher at $\mathrm{H} 3$ than at $\mathrm{H} 1$ and $\mathrm{H} 2$, whereas seed length of Fehu and Cavi was similar between harvest dates. The seed weight (expressed as 100-seed weight) was numerically highest at H3 (64 mg) followed by $\mathrm{H} 2$ (57 mg) and $\mathrm{H} 1$ (54 mg), whereas it was numerically highest in Fedo $(73 \mathrm{mg})$ followed by Fehu $(68 \mathrm{mg})$ and Cavi $(34 \mathrm{mg})$. As the highest seed weight was observed at $\mathrm{H} 3$, it suggests that the harvest date at 35 days after anthesis was the closest to physiological maturity of the seed, the point at which the maximum dry weight accumulation occurs [6]. Also, at the species level, seed size was associated with individual adult size, which agreed with results of studies reviewed by [28]. On average $(n=30)$, Fedo $(44 \mathrm{~cm})$ is taller than Fehu $(34 \mathrm{~cm})$ and the latter taller than Cavi $(22 \mathrm{~cm})$. Moreover, it has been argued that seed size evolves as part of a variety of life history traits, including plant size, plant longevity, juvenile survival rate, and time to reproduction [29].

Seed viability was affected by harvest date $(p<0.05)$ and by species $(p<0.01)$ (Table 3$)$. There was no interaction $(p>0.05)$ between harvest date and species. Seed viability was higher at $\mathrm{H} 2$ and $\mathrm{H} 3$ than at $\mathrm{H} 1$, which may indicate that a period of 21 days after anthesis is not enough for some seeds to develop a functional, mature embryo. At the species level, seed viability was highest in Cavi, intermediate in Fedo, and lowest in Fehu. The latter species had viability values below the germination values (described below), possibly caused by the sample size and/or difficulty in 
TABLE 3: Seed viability (average $\pm 1 \mathrm{SE}$ ) of the three perennial grasses studied.

\begin{tabular}{lcccc}
\hline \multirow{2}{*}{ Species } & \multicolumn{4}{c}{ Harvest date } \\
& H1 & H2 & H3 & Average \\
\hline & \multicolumn{4}{c}{$\%$} \\
Fedo & $30 \pm 9.1^{\mathrm{Bb}}$ & $55 \pm 5.0^{\mathrm{Aa}}$ & $60 \pm 5.8^{\mathrm{Aa}}$ & $48 \pm 5.3^{\mathrm{B}}$ \\
Fehu & $15 \pm 2.9^{\mathrm{Ba}}$ & $23 \pm 7.5^{\mathrm{Ba}}$ & $33 \pm 6.3^{\mathrm{Ba}}$ & $24 \pm 3.8^{\mathrm{C}}$ \\
Cavi & $55 \pm 2.9^{\mathrm{Aa}}$ & $70 \pm 4.1^{\mathrm{Aa}}$ & $55 \pm 6.5^{\mathrm{Aa}}$ & $60 \pm 3.3^{\mathrm{A}}$ \\
\hline Average & $33 \pm 5.8^{\mathrm{b}}$ & $49 \pm 6.7^{\mathrm{a}}$ & $49 \pm 4.8^{\mathrm{a}}$ \\
\hline
\end{tabular}

Fedo, Festuca dolichophylla; Fehu, Festuca humilior; Cavi, Calamagrostis vicunarum harvested at three times after anthesis (H1, 21 days; $\mathrm{H} 2,28$ days; $\mathrm{H} 3,35$ days). Means with different superscripts in the same row (lowercase letters) or in the same column (uppercase letters) are significantly different $(p<0.05)$.

assessing viability. Seeds that did not develop an intense redstained embryo (embryo stained pale pink) may have been erroneously assessed as dead because specific test information is not available for the studied species. Problems in assessing seed viability of native grasses have previously been reported [30]. The overall average seed viability was relatively low (compared to that of domesticated grasses), but like that reported for other native grasses [27].

Seed germination was not affected by harvest date $(p>0.05)$, but it was affected by species $(p<0.01)$ (Table 4$)$. There was no interaction $(p>0.05)$ between harvest date and species. Germination percentage was higher for Fehu and Cavi than for Fedo. However, regardless of the species, the germination percentages were low, which could be attributed to both dead and dormant seeds. On the one hand, the percentage of viable seeds was in a range of $15-70 \%$ (overall mean $44 \%$, Table 3). On the other hand, the germination percentage was always below the viability percentage, except for Fehu (as previously stated), which indicates the occurrence of seed dormancy. In the puna rangelands, seeds of the studied species are produced at the end of summer-beginning of autumn and they remain dormant in the soil seed bank throughout the rest of autumn and winter until germinating in the spring. This seed phenological pattern suggests that a period of chilling is required before germination is possible [31,32]. Although seeds were exposed to chilling conditions until the emergence of the radicle in the least dormant ones, it is possible that the duration of the chilling period may had been not enough to break the innate dormancy in some seeds.

In summary, our results are in overall agreement with previous studies (e.g., [11, 12, 33-35]) on domesticated and native seeds showing that seed maturity at harvest influences all readily measurably seed quality parameters, with their maximum expression closely related to the occurrence of seed physiological maturity [6]. The stage of seed maturity at harvest is also the main determinant of seed vigor [36], a trait defined as the sum of those properties of seeds that defines their ability to germinate and establish seedlings across diverse environmental conditions [37]. Harvesting before seed physiological maturity may result in low vigor since not all seed vigor characteristics have been acquired yet, whereas
TABLE 4: Seed germination (average \pm 1 SE) of the three perennial grasses studied.

\begin{tabular}{lcccc}
\hline \multirow{2}{*}{ Species } & \multicolumn{4}{c}{ Harvest date } \\
& $\mathrm{H} 1$ & $\mathrm{H} 2$ & $\mathrm{H} 3$ & Average \\
\hline \multirow{4}{*}{$\%$} & $\%$ \\
Fedo & $19 \pm 5.2^{\mathrm{Aa}}$ & $15 \pm 4.6^{\mathrm{Ba}}$ & $20 \pm 3.5^{\mathrm{Ba}}$ & $18 \pm 2.4^{\mathrm{B}}$ \\
Fehu & $28 \pm 3.2^{\mathrm{Aa}}$ & $38 \pm 4.3^{\mathrm{Aa}}$ & $35 \pm 5.4^{\mathrm{Aa}}$ & $34 \pm 2.6^{\mathrm{A}}$ \\
Cavi & $33 \pm 4.3^{\mathrm{Aa}}$ & $25 \pm 0.0^{\mathrm{Ba}}$ & $30 \pm 3.5^{\mathrm{ABa}}$ & $29 \pm 1.9^{\mathrm{A}}$ \\
\hline Average & $27 \pm 2.8^{\mathrm{a}}$ & $26 \pm 3.4^{\mathrm{a}}$ & $28 \pm 2.9^{\mathrm{a}}$ \\
\hline
\end{tabular}

Fedo, Festuca dolichophylla; Fehu, Festuca humilior; Cavi, Calamagrostis vicunarum harvested at three times after anthesis (H1, 21 days; $\mathrm{H} 2,28$ days; H3, 35 days). Means with different superscripts in the same row (lowercase letters) or in the same column (uppercase letters) are significantly different $(p<0.05)$.

harvesting too late may decrease enzymatic activity and gene expression and increase the risk of shattering and/or seed deterioration due to unfavorable weather conditions [38]. Since proper harvest time should be expected to vary jointly with variations in environmental conditions, it is important to explore convenient easy-to-measure surrogates for evaluating seed quality and vigor (e.g., [39]).

The effectiveness of seed-based restoration programs is highly dependent on seed quality assurance. This affirmation is presently more critical than ever to meet the challenges and goals of the United Nations Decade of Ecosystem Restoration (2021-2030). Seed harvest time is just one of the elements of the native seed supply chain [3]. The other elements are processing (cleaning and quality testing [40]) and storage and seed enhancement (treatments applied to the seed to enhance germination [41]). Seed cleaning and enhancement are critical when seed purity is low and seed dormancy high, as was the case for the three key perennial grasses native to puna tussock rangelands of Peru in the present study.

\section{Conclusions}

Seed quality parameters of the species studied did not show consistent variation over the harvest times, although maximum values of seed quality parameters were observed at 35 days from anthesis, when seeds were reaching physiological maturity. Due to interannual variations in the environmental conditions that influence seed physiological maturity, it would be important to identify proxies (such as seed colour, seed mass, seed water concentration, and growing degree days after anthesis) that coincide with seed physiological maturity to adjust the harvest time properly. However, the overall seed quality of the species studied was relatively low in terms of purity, viability, and germination. Therefore, when using seeds of $F$. dolichophylla, F. humilior, and $C$. vicunarum in rehabilitation programs on the puna rangelands, it is important to carry out a previous cleaning process (to reduce nonviable seeds and inert matter), to apply seed enhancement treatments to break dormancy, and to use a sufficient quantity of seed for effective establishment of these grasses. 


\section{Data Availability}

The data used to support the findings of this study are available from the corresponding author upon request.

\section{Conflicts of Interest}

The authors declare that there are no conflicts of interest.

\section{Acknowledgments}

The authors thank the SAIS Tupac Amaru for allowing them to use their lands and the FONDECYT for financial support to cover research expenses.

\section{References}

[1] D. D. Briske, "Rangeland systems: foundation for a conceptual framework," in Rangeland Systems: Processes, Management and Challenges, D. D. Briske, Ed., Springer, Cham, Switzerland, pp. 1-21, 2017.

[2] G. D. Gann, T. McDonald, B. Walder et al., International Principles and Standards for the Practice of Ecological Restoration, Society for Ecological Restoration, Washington, DC, USA, 2nd edition, 2019.

[3] S. Pedrini and K. W. Dixon, "International principles and standards for native seeds in ecological restoration," Restoration Ecology, vol. 28, pp. S286-S303, 2020.

[4] K. P. Vogel, "The challenge: high quality seeds of native plants to ensure successful establishment," Seed Technology, vol. 24, no. 1, pp. 9-15, 2002.

[5] M. B. McDonald, L. O. Copeland, A. D. Knapp et al., "Seed development, germination and quality," in Cool-Season Forage Grasses, L. E. Moser, D. R. Buxton, and M. D. Casler, Eds., pp. 15-67, ASA, CSSA and SSSA, Madison, WI, USA, 1996.

[6] T. Bareke, "Biology of seed development and germination physiology," Advances in Plants and Agriculture Research, vol. 8, no. 4, pp. 336-346, 2018.

[7] H. M. Roberts, "Harvesting S352 timothy for seed," Grass and Forage Science, vol. 24, no. 1, pp. 14-16, 1969.

[8] M. J. Hill and B. R. Watkin, "Seed production studies on perennial ryegrass, timothy and prairie grass. 2 . Changes in physiological components during seed development and time and method of harvesting for maximum seed yield," Grass and Forage Science, vol. 30, no. 2, pp. 131-140, 1975.

[9] H. Horton, K. H. Asay, T. F. Glover et al., Grass Production Guide for Utah, USDA-ARS, Logan, UT, USA, 1990.

[10] R. P. Andrade, D. F. Grabe, and D. Ehrensing, "Seed maturation and harvest timing in turf type tall fescue," Journal of Applied Seed Production, vol. 12, pp. 34-46, 1994.

[11] J. D. Berdahl and A. B. Frank, "Seed maturity in four coolseason forage grasses," Agronomy Journal, vol. 90, no. 4, pp. 483-488, 1998.

[12] M. A. Ruiz, M. A. Pérez, J. A. Argüello et al., "Madurez fisiológica de la semilla de Bromus auleticus Trin. (cebadilla chaqueña)," Revista de Investigaciones Agropecuarias (RIA), vol. 32, no. 2, pp. 3-20, 2003.

[13] J. Lin, Y. Wang, M. Qi et al., "Optimum harvest maturity for Leymus chinensis seed," Biology Open, vol. 5, no. 6, pp. 720-725, 2016.

[14] E. R. Flores, J. A. Naupari, and R. E. Tácuna, "La economía del cambio climático en el Perú: ganadería altoandina," in $L a$ economía del cambio climático en el Perú, Comisión
Económica para América Latina y el CaribeBanco Interamericano de Desarrollo, Lima, Perú, 2014.

[15] J. C. Postigo, K. R. Young, and K. A. Crews, "Change and continuity in a pastoralist community in the High Peruvian Andes," Human Ecology, vol. 36, no. 4, pp. 535-551, 2008.

[16] E. R. Flores, "Climate change: high Andean rangelands and food security," Revista de Glaciares y Ecosistemas de Montaña, vol. 1, pp. 73-80, 2016.

[17] C. Turin, Perceptions of Rangeland Degradations and its Causes in the Peruvian Altiplano Dry puna PhD Dissertation, University of Missouri, Columbia, MU, USA, 2019.

[18] SENAMHI, Servicio Nacional de Meteorología e Hidrología del Perú, Lima, P., 2020, URL httpps://www. Gob.pe/senamhi.

[19] J. Castro, Momento de cosecha y capacidad de germinación de semillas de tres gramíneas altoandinas (Festuca dolichophylla, Festuca humilior y Calamagrostis vicunarum), MSc Thesis, Universidad Nacional Agraria La Molina, Lima, Perú, 2019.

[20] ISTA (International Seed Testing Association), International Rules for Seed Testing, ISTA, Zurich, Switzerland, 2016.

[21] R. J. Provert, "The role of temperature in the regulation of seed dormancy and germination," in Seeds: The Ecology of Regeneration in Plant Communities, M. Fenner, Ed., pp. 261-292, CABI Publishing, Wallingford, UK, 2nd ed. edition, 2000.

[22] W. E. Finch-Savage and G. Leubner-Metzger, "Seed dormancy and the control of germination," New Phytologist, vol. 171, no. 3, pp. 501-523, 2006.

[23] S. Abel and B. Boelt, "Precipitation during anthesis reduces seed set in perennial Ryegrass," Grass and Forage Science, vol. 73, no. 1, pp. 239-246, 2018.

[24] D. S. Loch, P. W. Johnston, T. A. Jensen, and G. L. Harvey, "Harvesting, processing, and marketing Australian native grass seeds," New Zealand Journal of Agricultural Research, vol. 39, no. 4, pp. 591-599, 1996.

[25] T. J. Gutormson and A. L. Patin, "Sources of laboratory test result variation in warm-season grasses," Seed Technology, vol. 24, no. 1, pp. 52-61, 2002.

[26] K. R. Jorgensen and R. Stevens, "Seed collection, cleaning, and storage," in Restoring Western Ranges and Wildlands, S. B. Monsen, R. Stevens, and N. L. Shaw, Eds., USDA Forest Service General Technical Report RMRS-GTR-136, Fort Collins, CO, USA, 2004.

[27] S. M. Bellairs and M. J. Caswell, "Seed viability of native grasses is important when revegetating native wildlife habitat," Northern Territory Naturalist, vol. 27, pp. 36-46, 2016.

[28] M. Westoby, E. Jurado, and M. Leishman, "Comparative evolutionary ecology of seed size," Trends in Ecology \& Evolution, vol. 7, no. 11, pp. 368-372, 1992.

[29] A. T. Moles and M. Westoby, "Seed size and plant strategy across the whole life cycle," Oikos, vol. 113, no. 1, pp. 91-105, 2006.

[30] G. J. Farley, S. M. Bellairs, and S. W. Adkins, "Germination of selected Australian native grass species, with potential for minesite rehabilitation," Australian Journal of Botany, vol. 61, no. 4, pp. 283-290, 2013.

[31] K. Thompson and J. P. Grime, "Seasonal variation in the seed banks of herbaceous species in ten contrasting habitats," Journal of Ecology, vol. 67, no. 3, pp. 893-921, 1979.

[32] J. R. Goodwin, P. S. Doescher, and L. E. Eddleman, "Afterripening in Festuca idahoensis seeds: adaptive dormancy and implications for restoration," Restoration Ecology, vol. 3, no. 2, pp. 137-142, 1995.

[33] D. M. Tekrony and D. H. Egli, "Accumulation of seed vigour during development and maturation," in Basic and Applied Aspects of Seed Biology, R. H. Ellis, M. Black, A. J. Murdoch 
et al., Eds., Kluwer Academic Publishers, Dordrecht, Netherlands, pp. 369-384, 1997.

[34] P. Wang, D. W. Zhou, and I. Valentine, "Seed maturity and harvest time effects seed quantity and quality of Hordeum brevisubulatum," Seed Science \& Technology, vol. 34, no. 1, pp. 125-132, 2006.

[35] H. M. I. Zadeh, T. M. Mahmoodi, and N. Khaliliaqd, "Effect of different harvesting times on the seed quality of barley cultivars," Journal of Biological Sciences, vol. 14, no. 8, pp. 532-536, 2014.

[36] M. Zhu, X. Yu, G. Zhao, and L. Wang, "Effects of harvest time on seed vigor, enzyme activity and gene expression of conventional japonica rice," Archives of Agronomy and Soil Science, vol. 44, pp. 1-16, 2020.

[37] W. E. Finch-Savage and G. W. Bassel, "Seed vigour and crop establishment: extending performance beyond adaptation," Journal of Experimental Botany, vol. 67, no. 3, pp. 567-591, 2016.

[38] O. Leprince, A. Pellizzaro, S. Berriri, and J Buitink, "Late seed maturation: drying without dying," Journal of Experimental Botany, vol. 68, no. 4, pp. 827-841, 2017.

[39] D. Wen, H. Hou, A. Meng, J. Meng, L. Xie, and C. Zhang, "Rapid evaluation of seed vigor by the absolute content of protein in seed within the same crop," Scientific Reports, vol. 8, no. 1, p. 5569, 2018.

[40] S. Frischie, A. L. Miller, S. Pedrini et al., "Ensuring seed quality in ecological restoration: native seed cleaning and testing," Restoration Ecology, vol. 28, pp. S239-S3248, 2020.

[41] S. Pedrini, A. Balestrazzi, M. D. Madsen et al., "Seed enhancement: getting seeds restoration-ready," Restoration Ecology, vol. 28, pp. S266-S3275, 2020. 